\title{
Pushed Output and Noticing in a Dictogloss: Task Implementation in the CLIL Classroom
}

\author{
MARÍA BASTERRECHEA \\ María del Pilar García Mayo \\ Universidad del País Vasco (UPV/EHU) \\ Michael J. LeESER \\ The Florida State University
}

Received: 12 February 2013 / Accepted: 30 July 2013

ISSN: $1697-7467$

\begin{abstract}
This study investigates the role of output tasks in noticing a certain target form upon receiving subsequent input. Sixteen adolescent learners from an intact CLIL classroom carried out a multi-stage dictogloss task collaboratively and individually. They followed the usual steps in this type of task (listen and jot down key words, text reconstruction). Then they listened to the text once again and compared it with their production. The study revealed that (a) pushed output affects noticing in subsequent input and provides learners the opportunity to notice formal aspects of language and (b) pairs working in collaboration did not obtain better results.

Key words: Content and Language Integrated Learning (CLIL), output-input cycle, collaborative tasks, dictogloss and noticing

Producción inducida y la detección en la dictoglosia: implementación de tareas en el aula AICLE

RESUMEN: El presente estudio investiga cómo una tarea productiva puede promover la atención a la forma al recibir input tras dicha producción. Dieciséis aprendices adolescentes llevaron a cabo una dictoglosia en varios pasos de forma colaborativa e individual de la siguiente forma: escucharon un texto y anotaron palabras clave, reconstruyeron el texto; volvieron a escuchar el texto y lo compararon con su producción escrita. Los resultados revelaron que (a) la producción y consiguiente input son beneficiosos, dado que los aprendices dirigieron su atención a aspectos formales de la lengua; (b) los alumnos que trabajaron en grupo no obtuvieron mejores resultados.

Palabras clave: Aprendizaje integrado de contenidos y lengua (AICLE), ciclo de producción-recepción, tareas colaborativas, dictoglosia y atención
\end{abstract}

\section{INTRODUCTION}

Research on second language acquisition (SLA) has provided support for the facilitative role of pushed output in the acquisition process (Swain, 2005), especially when learners carry out tasks collaboratively (Storch, 2005). Swain (1995) proposed three potential functions that output plays in in the process of acquiring a second language (L2): (a) noticing/triggering 
of specific aspects of the target language: producing the target language may lead learners to notice a hole in their interlanguage (Selinker, 1972)); (b) hypothesis testing: learners may receive feedback by trying out new forms and structures; (c) conscious reflection on output upon production: learners can explicitly hypothesize about language itself by consciously reflecting on it.

Research on the noticing function of output (Izumi, 2002) is based on the premise that directing learners' attention to form during otherwise meaning-oriented learning helps them to acquire form and meaning in an integrated way. However, a research issue that has received relatively less attention and has produced quite mixed results is whether output tasks promote better noticing and learning of a targeted linguistic form than non-output task conditions (Leeser, 2008; Song \& Suh, 2008).

Drawing on the psycholinguistic rationale and empirical research on output, the present small-scale study set out to explore the effect of output-input cycles on Contentand-Language-Integrated-Learning (henceforth CLIL) learners' noticing and production of English verb tenses in a multi-stage dictogloss task. CLIL is an educational approach where a foreign language is used as a medium of instruction of a content subject with a dual focus on form and content (Lorenzo, et al., 2009), a setting where, to the best of our knowledge, the effect of learners' production upon receiving subsequent input has not been investigated yet. The present study seeks to investigate what the act of receiving input after production can reveal about how and whether production prompts these learners to seek solutions in subsequent input while completing a subject-specific task about a topic of the course content. In addition, we aimed to assess whether collaborative work can be beneficial in this learning context, where increased exposure and a purportedly more interactive methodology may have a positive effect on learners' attention to form, an issue that has hardly been investigated (e.g., Basterrechea \& García Mayo, 2013). The paper is structured as follows. Section 2 presents the theoretical framework and the main findings regarding the noticing function of output (Swain, 1995), research findings obtained comparing tasks carried out collaboratively and individually, and a brief overview of retrospective protocols. Section 3 describes the participants, materials employed and the procedure we followed. Section 4 presents the results, and section 5 concludes the paper pointing out limitations and offering lines for further research.

\section{THEORETICAL FRAMEWORK}

\subsection{The noticing function of output}

\subsubsection{Noticing}

Noticing is a mechanism that mediates between communication and acquisition (Gass, 2003: 224). According to Schmidt (1990), noticing is conscious attention to input, and noticing something in the input is crucial for acquisition to take place. "Noticing is the necessary and sufficient condition for converting input into intake" (1990: 129). Swain (1985) claimed that when learners are pushed to produce language, they may notice the gap between what they intend to utter and what their interlanguage allows them to say. As Kuiken and Vedder 
(2005: 327) note, there seems to be a connection between learners' noticing of linguistic forms in the input and successful learning. However, it is not clear if focusing on a particular language form promotes the acquisition of that form (Schmidt, 1990, 1995; VanPatten, 1996, 2000; VanPatten \& Cadierno, 1993).

\subsubsection{The noticing function of output in multi-stage tasks}

Recently, several researchers have investigated the role that language production plays in noticing, examining whether the act of producing output (orally or written) affects the noticing of linguistic elements in the target language. As mentioned above, it is widely agreed that producing language constitutes an essential part in L2 learning, but how learner attentional processes may be influenced by L2 production has not been clearly investigated yet (Izumi, 2002). Through output, learners' attention arises from the learners' need; thus output can be considered a learner-internal attention-drawing device (op. cit, 2002: 543). Current research posits that production constitutes an essential factor in L2 learning, and not only an opportunity for practising for greater fluency (Swain, 1985 et passim). Several researchers have examined the role of pushed output in noticing and the effect of receiving subsequent input (i.e., after production has taken place), by which output may serve as an attentionfocusing device in carefully-planned multi-stage tasks (Izumi, 2002; Izumi \& Bigelow, 2000; Izumi et al., 1999; Leeser, 2008; Song \& Suh 2008; Uggen, 2012). In all these studies, in order to determine how output promotes noticing, learners are engaged in carefully-planned multi-stage tasks, by means of which in an output-input cycle learners are pushed in their production and can compare it with the input subsequently received (i.e., they listen to the text once again). This comparison aids learners in seeking relevant linguistic forms in order to convey meaning more accurately (Thornbury, 1997). Noticing is operationalized as notes taken in the input turn, i.e., when receiving the aural stimulus or as underlines in a written text. Results in these studies are mixed. Izumi and Bigelow (2000) and Izumi et al. (1999) analysed the English past hypothetical conditional with a heterogeneous group of ESL learners ${ }^{1}$, and they found that learners did not encounter more instances of the target feature under study than those who answered questions on content. The researchers hypothezised that the learners focused on problematic areas different from what the researchers had in mind in their study. Izumi (2002) analysed the effect of receiving written input after written production and textual enhancement (Sharwood Smith, 1993) ${ }^{2}$ with English relative clauses produced by a group of ESL learners with different L1 backgrounds (e.g., Arabic, Chinese, French or Spanish) in two U.S. universities. Although learners in both enhanced and output conditions outperformed the control group, those who produced output scored significantly higher than those who were involved in a task with input enhancement. Exposure to input after production heighthened the sense of problematicity and learners paid closer attention to what was difficult for them in their interlanguage.

Leeser (2008) analysed the use of the imperfect and preterite (past simple) in a dictogloss task completed by English speakers learning Spanish, a problematic distinction of L2 Spanish

${ }^{1}$ The authors do not specify the L1 backgrounds of the participants in the study.

${ }^{2}$ Input enhancement is a kind of noticing by which targeted linguistic features of the input are made salient (Thornbury, 1997), so that learners can attend to them. 
learners (e.g., Bardovi-Harlig, 2000; Montrul, 2005). Once again, the learners were engaged in an output-input cycle in a close-ended information task. Noticing was operationalized as notes taken in the second input turn. The findings showed that pushed output did not promote noticing of past forms, although there was an increase in attempts of proper uses of the imperfect on the post-treatment. Comparing pre-treatment and post-treatment writings, results showed a decrease in non-targetlike forms and an increase in their attempted uses of past tense morphology. Leeser (2008) concluded that learners were gaining control over the preterite and were improving the use of the imperfect form.

In an EFL context, Song and Suh (2008) compared noticing of the English past counterfactual conditional by Korean EFL learners using a text reconstruction task and a picturecued writing task. Noticing was operationalized as underlining. Results showed that there were no differences between the first and the second input turn in noticing the target form. Additionally, the authors acknowledged that the fact that the learners were informed about the task they would accomplish biased the results. Recently, Uggen (2012) has replicated Izumi and Bigelow's (2000) study with university students from different L1 backgrounds (e.g., Korean, Arabic, or Mandarin) in the U.S., too. Besides underlining, a stimulated recall protocol was used as a noticing measure (see 2.3. Retrospective protocols section for details) with English present and past hypothetical conditionals, the assumption being that underlining may not be enough to give account for what learners notice. In a stimulated recall (also called retrospective protocol), learners are interviewed by the researcher, generally after they are finished with a task, in order to analyse their metalinguistic reflections; that is, reflections on language learners engage in while comprehending and producing language (Suzuki \& Itagaki, 2007:132). The written production of the target forms after the first and the second input turns was also analysed. Results showed that learners increased the correct use of the past hypothetical conditional from the first to the second written productions, although only 8 students (out of 30 ) produced those forms. Underlining showed that only 5 students underlined target forms, supporting Izumi and Bigelow's (2000) observation that underlining is a relatively uninformative source of evidence of what has been noticed. Similarly, in the stimulated recall learners referred to general grammar issues. However, there was a significant language gain on the post-test for the past hypothetical conditional, a result that shows that even if underlining did not provide evidence that the target feature was noticed, the output-input cycle, overall, was beneficial for the use of this form.

In summary, experimental studies on multi-staged task have not reported clear benefits for those learners who were provided with extra input to foster noticing of specific grammatical forms. In some of the studies, the researchers acknowledge design problems. For instance, in the studies by Izumi and Bigelow (2000) and Song and Suh (2008), once every treatment group was informed of the type of task they would accomplish in advance, they underlined those features they would need for the task they had been assigned. That is, their attention was drawn and consequently biased due to the fact that they "foreknowledged the tasks" (Song \& Suh, 2008: 306). On the other hand, their negative results may be attributable to the way in which noticing was operationalized. Underlines may not be a good noticing measure, as already observed by Izumi and Bigelow (2000) and Uggen (2012), as non-underlined features may not necessarily go unnoticed. In addition, in Izumi et al. (1999), Izumi (2002) and Leeser (2008), noticing was operationalized as the notes the learners took in the input turns. We believe that the notes the learners take in these turns may not 
necessarily have a grammatical focus, but they are more likely to focus on meaning with the idea of reconstructing the passage later on. Following these observations, in our study, we operationalized noticing as production of the target feature in the written task, and we also adopted a retrospective protocol as a complementary measure to assess noticing, as in the study by Uggen (2012).

\subsection{Tasks and collaborative work}

Collaborative work has received a great deal of attention in recent empirical research. Collaborative form-focused tasks integrate both attention to form and communicative interaction by means of a natural and communicative use of the target language. Several recent studies investigate the role of interaction and the effectiveness of task-based collaborative work in ESL, EFL and Spanish-as-a-foreign-language contexts, with jigsaw (Fernández Dobao, 2012), cloze (Nassaji \& Tian, 2010; Storch, 1999), or editing tasks (Storch, 2007). These studies investigate the role of interaction comparing the learners' performance in collaboration and individually. Dictogloss (Wajnryb, 1990) is among the collaborative writing tasks that research has proven effective in terms of attention to form (Alegría de la Colina \& García Mayo, 2007; Swain, 1998; Swain \& Lapkin, 2001) and it is the task type chosen for the present study. In a dictogloss task, a short text is read twice at normal speed: the first time learners listen, and the second time they jot down words. Then, individually or collaboratively, learners pool their resources to reconstruct the text they have listened to as faithfully as possible. For instance, Kuiken and Vedder (2005) analysed how the outcome of a dictogloss task differed in collaborative and individual conditions. The linguistic focus under study was the passive in English, and the participants were high-school students. The interaction of those students working collaboratively was recorded and analysed. Results showed that those who reconstructed the text collaboratively did not produce more instances of the passive verb form. However, interaction among the participants did stimulate noticing of the target form.

Overall, these studies have yielded disparate results (e.g., Fernández Dobao, 2012; Storch, 1999, with positive results, and Kuiken \& Vedder, 2005; Nassaji \& Tian, 2010; Storch, 2007, with negative or non-significant differences) which call into question the benefits of collaborative work. What is clear is that more empirical research comparing small group and individual work is needed (Storch, 2007). Additionally, little research on peer interaction has been carried out in the CLIL classroom (e.g., Basterrechea \& García Mayo, 2013; Nikula, 2012). We believe that a CLIL classroom is a good testing ground to assess collaborative work, as it is a teaching methodology where learner-learner interaction and dialogic activity need to be promoted (Coyle, 2007).

\subsection{Retrospective protocols}

In interaction research it is becoming common to examine the retrospective comments the learners make after having worked together to reconstruct a task; this is a type of methodological technique known as stimulated recall or retrospective protocol (Gass \& Mackey, 2000) (see 2.2.2. The noticing function of output in multi-stage tasks for details). Metalinguistic reflections have been claimed to be an important source of second language 
learning (Swain, 2005). In a study by Mackey et al. (2000), learners engaged in a two-way information exchange activity with a native or near-native interviewer, who provided the learners with feedback. The interactions were videotaped. Once they finished, the learners, together with the researcher, watched the recording of their interaction and were asked to recall their thoughts in order to jog up their memories about what they had said while completing the task. As explained above, Uggen (2012) used a stimulated recall protocol as an additional noticing measure. The learners in the study were videotaped as they received input in the form of a model essay containing the target feature. After they finished the task, the learners watched the recording. When the researcher realized that noticing operationalized as episodes that involved underlining or hesitation seemed to occur, the researcher stopped the recording and asked the learners to recall their thoughts.

Learners can also write about their thinking processes and reflect on how they solved their task. In a study by Suzuki and Itagaki (2007), the researchers were interested in the kind of metalinguistic reflections the learners engaged in after performing an output-oriented task. Intermediate and advanced Japanese learners of English were asked to write about how they solved two tasks (i.e., translation and scrambled sentences). Once they received explicit feedback in the form of a correct solution, learners wrote about their thinking processes. Learners' metalinguistic reflections showed how they noticed linguistic forms and tested hypotheses, which supported the Output Hypothesis (Swain, 1995): learners' conscious metalinguistic reflection allowed them to control and internalize linguistic knowledge. This type of reflections encouraged learners to engage in syntactic processing, which is a major cognitive process in second language acquisition (Suzuki \& Itagaki, 2007).

Based on the theoretical background and the findings from the research summarized above, the present study addresses the following research questions:

1. Does pushed output (production) in a dictogloss task affect learners' noticing of English verb forms on subsequent input?

2. Does collaborative reconstruction lead to more noticing of the target form than individual work?

3. What kinds of written metalinguistic reflections do learners engage in after performing a multi-stage dictogloss task?

\section{THE STUDY}

\subsection{Purpose of the study}

The present study aims to assess whether CLIL learners' output while completing a dictogloss task is affected by subsequent input. As seen above, research has examined the effect of production on learners' attention to form in ESL and EFL contexts, but, to our knowledge, the issue has not been investigated in a CLIL context to date. More specifica1ly, we aim to explore if a multi-stage dictogloss task can foster attention to form (English present and past tenses) in this setting with a subject-specific text about the course content in a History lesson. Its second aim is to analyze whether collaborative work is more beneficial than individual work while completing this task. Finally, we are also interested in 
assessing whether learners engage in some type of metalinguistic reflections after performing a multi-stage dictogloss task.

\subsection{The setting and participants}

The present study was carried out in the Basque Autonomous Community (B.A.C.) in an intact classroom with adolescent bilingual learners in their last year of compulsory secondary education. The participants were about to complete a multilingual project, where English is introduced at the age of four. The project culminates with the adoption of a CLIL approach in the final stages of Secondary Compulsory Education (with students aged between 14 and 16). It is then when Social Sciences is taught through English (Human Geography in $3^{\text {rd }}$ year, and Modern History in $4^{\text {th }}$ year) (Ball et al., 2004). The students also have their regular English as a school subject classes. All the learners participating in this study have been exposed to English for 12 years in a classroom setting (1520 hours approximately).

Sixteen (16) students ( 5 males, 11 females) from an intact classroom participated in the study. The Social Sciences teacher, a native speaker of English, considered that the students' proficiency level was equivalent to B1 (a lower autonomous user), according to the Common European Framework for Languages (Council of Europe, 2001), which is the proficiency level the students reach at the end of the $4^{\text {th }}$ year of compulsory secondary education. Additionally, they were former students of one of the researchers, who was consequently aware of the strengths and weaknesses of the group.

Table 1 provides information about the participants in this study:

Table 1. Participant distribution

\begin{tabular}{|c|c|c|}
\hline Participants & Age range & Age mean \\
\hline 16 & $15-17$ & 15.45 \\
\hline
\end{tabular}

In order to maintain the ecological validity of the study, the Social Sciences teacher agreed on the task type developed in the research and provided suggestions regarding the text to be reconstructed by the students and the level of difficulty of the aural input the students were to receive. Regarding the CLIL (Human Geography and History) class lectures in which the students participated, they focused on the course content established by the official curriculum; the students were exposed to a great deal of input from their teacher and the Modern History textbook. In the case of English lectures, they were equally exposed to a great deal of input, including all time references. The lessons integrated linguistic skills, focusing on grammar very frequently, including the use of the simple present. 


\subsection{Materials and procedure}

\subsubsection{Dictogloss task}

As previously stated, a type of text reconstruction task (i.e., dictogloss) was chosen for the present study. The passage was an adapted version of a text from their course materials used in their History class about The Berlin Wall ${ }^{3}$ in the form of a piece of news from 1961 published in Berlin during the Cold War. The text contained instances of present and past tenses (see Appendix).

\subsubsection{Procedure}

Eight students (four dyads) reconstructed the text collaboratively and, following Leeser's work (2008), eight more students reconstructed it individually. The students did not know in advance they were to perform different tasks, or the linguistic focus we were analysing (use of present and past tenses). In addition, they were asked not to turn pages back and forth in the experimental material so that their attention would not be drawn by different task characteristics, which biased the results in Izumi and Bigelow (2000) or Song and Suh's work (2008). Table 2 illustrates the different stages of the experimental procedure.

Table 2. Sequence of activities in the experimental design

\begin{tabular}{|l|l|}
\hline \multicolumn{1}{|c|}{ COLLABORATIVE DICTOGLOSS TASK } & \multicolumn{1}{c|}{ INDIVIDUAL DICTOGLOSS TASK } \\
\hline Listen twice - take notes & Listen twice - take notes \\
\hline Reconstruction 1 (in pairs) & Reconstruction 1 (individually) \\
\hline Listen to text - take notes & Listen to text - take notes \\
\hline Reconstruction 2 (in pairs) & Reconstruction 2 (individually) \\
\hline Retrospective questionnaire & Retrospective questionnaire \\
\hline
\end{tabular}

The participants completed a multi-stage dictogloss task, as follows:

(1) Learners listened to a short passage dealing with the course content (The Berlin Wall). They were asked to listen only and not write anything down. The text was read by a native speaker of English.

(2) Secondly, they listened to the passage again and were instructed to jot down notes in English.

(3) Next, pairs reconstructed the passage using the notes they had previously taken, and individuals reconstructed it using their own notes as well.

(4) Learners then listened to the passage a third time, took notes, and subsequently compared it with the text previously written (Thornbury, 1997).

\footnotetext{
${ }^{3}$ Text adapted from Social Sciences. Compulsory Secondary Education. Second cycle. Vol 3, page 21.
} 


\subsubsection{Retrospective questionnaire}

Finally, all groups completed a written retrospective questionnaire (Suzuki \& Itagaki, 2007 ) in order to share the metalinguistic reflections they engaged in while performing the dictogloss task. They were asked about 1) whether they had noticed any differences between the text they listened to the second and the third time (after production), and 2) the type of reflections (i.e., content or grammar) those in the collaborative condition had engaged in.

\subsection{Scoring and analysis}

Noticing was operationalized by tallying and comparing the number of correct instances of present and past tense forms in obligatory contexts between the first and second reconstructions, and between collaborative and those working individually. Finally, the written metalinguistic reflections the learners engaged in were analysed qualitatively in order to determine if they had focused on content or on grammar while performing the task.

\section{RESUlts}

In order to determine whether pushed output (i.e., production) in a dictogloss task affects learners' noticing of the target form upon receiving subsequent input, we compared the correct instances of the present and past tenses between the first and second reconstructions. Table 3 displays the mean raw and percentage scores for the correct uses of present tense in obligatory contexts (11) and of past tense in past (2) contexts. As the Table indicates, the number of correct uses from the first to the second text reconstructions increased. In order to determine whether this increase was significant, the scores were submitted to a pairedsamples t-test, as well as a nonparametric Wilcoxon Signed Ranks Test due to the low number of participants and non-normally distributed data. The $t$-test revealed that learners produced significantly more present tense forms on the second reconstruction than on the first, $(t(15)$ $=2.52, p=.023)$, as did the Wilcoxon Signed Ranks Test, $(z=2.26, p=.024)$. Neither test revealed a significant increase for correct usage of the past $(p$ 's $>.30)$.

Table 3. Descriptive statistics of correct present and past tense uses in obligatory contexts $(N=16)$ (Standard deviations are shown in brackets)

\begin{tabular}{lcccc}
\hline & \multicolumn{2}{c}{ Reconstruction 1 } & \multicolumn{2}{c}{ Reconstruction 2 } \\
\cline { 2 - 5 } & $\begin{array}{c}\text { Mean Raw Score } \\
\text { (S.D) }\end{array}$ & $\%$ & Mean Raw Score & $\%$ \\
& 1.06 & 9.66 & 1.63 & 14.77 \\
Present & $(2.05)$ & $(18.62)$ & $(2.36)$ & $(21.48)$ \\
& 0.75 & 37.50 & 0.81 & 40.63 \\
Past & $(0.93)$ & $(46.54)$ & $(0.91)$ & $(45.53)$ \\
& & & & \\
\hline
\end{tabular}


Results show that pushed output does affect learners' noticing of English present tense forms. Production (i.e., reconstructing the text) promoted noticing of this linguistic form upon receiving subsequent input. Table 3 shows that participants significantly improved their production due to the fact that exposure to input after production gave learners the opportunity to pay closer attention to formal aspects. The following are some examples of learners' production and how pushed output promoted noticing on subsequent input ${ }^{4}$.

(1) TR1: a young man who work in the West and live in the East.

TR2: a young man who lives in the West and has a job in the East.

(2) TR1: if someone lives in the East and have the work in the West...

TR2: A young man that lives in the East and works in the West...

(3) TR1: The students couldn't go to the university.

TR2: The students can't go to the university.

In examples (1) and (2), the learners clearly correct the $3^{\text {rd }}$ person singular, present tense in the second reconstruction, and in example (3) the verb tense is corrected, by comparing their original output with subsequent input, which lends support to the hypothesized effect of pushed output (Swain, 1995) in triggering noticing.

Thus, receiving input after production can push the learners to process the input effectively, since exposure to input after production may have heighthened the sense of problematicity, as already observed by Izumi (2002). Based on the results in the present study, we can conclude that this kind of form-focused task does promote noticing (or some kind of form processing in the input). It therefore supports one of the claims of Swain's (1995) Output Hypothesis.

It is worth noting, however, that some of the students used the past tense in their final production. We could speculate that they are circumventing the present tense form based on their expectations; that is, they used the past tense in their reconstructions because the pastness feature of the events described in the text (a piece of news published back in 1961) prevailed over the grammatical forms, which is part of Swain's (1985 et passim) point: left to their own devices, learners are engaging in semantic processing and not in deeper syntactic processing. However, production led some of the students to notice a gap between what they produced and the grammatical forms in the passage to be reconstructed, which in turn led them to consciously recognize the difference between what they produced in the first reconstruction and what they needed to discover about the actual passage. These findings support the noticing role of output as a "consciousness-raising function" (Swain 1995: 129), in the sense that some learners in the present study consciously noticed the linguistic form under study, and noticing led learners to recognize what they needed to be aware of in their second language.

Research question 2 referred to results regarding collaborative and individual work. In line with previous literature on the topic reported above, we wanted to examine if collaborative work would yield more positive results than individual work. Table 4 displays the

${ }^{4}$ TR1 refers to the first text reconstruction (which took place after receiving the input twice), and TR2 to the second reconstruction (after listening to the text a third time); changes from one reconstruction to the other are shown in italics. 
mean uses of present forms for the collaborative and individual output groups on the first and second reconstructions, and Table 5 shows the mean number of present forms added and changed from the first to the second reconstructions. The data for the present tense forms on both reconstructions were submitted to a $2 \times 2$ ANOVA. The between-subjects variable was Group (collaborative vs. individual) and the within-subjects variable was Reconstruction (first vs. second). The ANOVA revealed a significant effect for Reconstruction, $(F(1,14)=$ $6.23, p=.026)$, indicating that learners produced a greater number of correct present tense uses on the second reconstruction than on the first. However, there was no effect for Group, $(F(1,14)=1.86, p=.194)$, and no significant Reconstruction $\times$ Group interaction, $(F(1,14)$ $=0.69, p=.419)$, suggesting that learners improved in their correct use of present tense forms regardless of whether they worked individually or collaboratively.

Table 4. Descriptive statistics of correct present form uses in first and second reconstructions in collaborative and individual groups (Standard deviations are shown in brackets)

\begin{tabular}{lcccc}
\hline & \multicolumn{2}{c}{ Reconstruction 1} & \multicolumn{2}{c}{ Reconstruction 2 } \\
\cline { 2 - 5 } & $\begin{array}{c}\text { Mean Raw Score } \\
\text { (S.D) }\end{array}$ & $\%$ & $\begin{array}{c}\text { Mean Raw Score } \\
\text { (S.D) }\end{array}$ & $\%$ \\
\hline Collaborative & 0.25 & 2.27 & 1.00 & 9.09 \\
& $(0.46)$ & $(4.20)$ & $(1.20)$ & $(10.87)$ \\
Individual & 1.88 & 17.05 & 2.25 & 20.45 \\
& $(2.70)$ & $(24.50)$ & $(3.11)$ & $(28.23)$ \\
\hline
\end{tabular}

Table 5. Descriptive statistics of correct present forms added and changed in first and second reconstructions in collaborative and individual groups

\begin{tabular}{lcccc}
\hline & \multicolumn{2}{c}{ Present Added } & \multicolumn{2}{c}{ Present Changed } \\
\cline { 2 - 5 } & $\mathrm{M}$ & $\mathrm{SD}$ & $\mathrm{M}$ & $\mathrm{SD}$ \\
\hline Collaborative & 0.38 & 0.51 & 0.38 & 0.74 \\
Individual & 0.00 & 0.00 & 0.38 & 0.74 \\
\hline
\end{tabular}

Results in Tables 4 and 5 show that the participants in the collaborative condition did not obtain better results than those working individually, suggesting that these learners did not benefit from being paired in production of the target feature under study; in other words, co-constructing the passage did not enhance learners' resources in terms of noticing and producing the target forms, giving and receiving feedback, or providing corrections and reassurance. In fact, learners working individually obtained better results in both reconstructions (see Table 4). Research question 3 referred to the kinds of written metalinguistic reflections learners engaged in after performing a dictogloss task. Recall that the two groups were asked if they had noticed any differences between the first input cycle (by which they listened to 
the passage twice) and the second input cycle (they listened to the passage a third time). Most students declared they completed or corrected pieces of information they had missed for the first reconstruction. Some referred to the fact that in the first reconstruction, they had written verbs in tenses different from the original text, but due to the low number of students who mentioned it, it cannot be considered significant.

We were also interested in the type of reflections the collaborative group engaged in while reconstructing the text in pairs. It seems that in the second input turn, they were more concerned about the events described in the text than about the features targeted by the task. Very few talked about grammar or spelling. In other words, the students' discussions in our study focused on content and added information missing from the first turn, as observed in Uggen's (2012) study. As Kuiken and Vedder (2005) point out, one of the conclusions drawn from their study where a dictogloss task was carried out individually and collaboratively (mentioned above) was that participants' discussions focused on the meaning they wanted to express. Certainly, it is difficult to predict which language areas will draw learners' attention in a form-focused task (cf. García Mayo, 2002: 169). Learners have their own agenda and they focus on areas different from those expected by the researcher (García Mayo, 2002; Izumi \& Bigelow, 2000; Izumi et al., 1999; Swain, 1995).

\section{Conclusion and future research}

This study set out to investigate the effect of output on CLIL learners' noticing of the English simple present and past tenses. In line with previous research, this study aimed to examine the effect of learners' production of pushed output upon receiving subsequent input and the benefits, if any, of that production when working collaboratively using a dictogloss task.

Briefly, the findings for our first research question (Does pushed output (production) in a dictogloss task affect learners' noticing of English verb forms on subsequent input?) suggest that production led students to notice the gap between what they produced and the grammatical forms in the passage to be reconstructed. In other words, pushed output did affect noticing of present forms in subsequent input and exposure to input after production gave learners the opportunity to pay closer attention to formal aspects. These findings suggest that the comparison of the production of the English present tense between the first and the second reconstructions may be an adequate noticing measure that can help us to examine how production affects learners' attentional processes. Research question 2 (Does collaborative reconstruction lead to more noticing of the target form than individual work?) considered whether collaborative work would be more beneficial than individual work while completing the dictogloss task. The findings in this study suggest that learners improved in their correct use of the target form regardless of whether they worked individually or collaboratively. In other words, co-constructing the passage did not enhance learners' resources, a finding obtained in numerous studies conducted so far (e.g., Kuiken \& Vedder, 2005; Nassaji \& Tian, 2010; Storch, 2007). Our final research question (What kinds of written metalinguistic reflections do learners engage in after performing a multi-stage dictogloss task?) focused on written metalinguistic reflections they completed after the dictogloss task. Due to the low number of answers obtained, no quantitative analysis has been carried out but it was 
interesting to see that students in the collaborative condition were more concerned about the events described in the text than about its grammatical features.

Overall, the findings of the study lend support to one of the claims in Swain's (1995) Output Hypothesis: our results indicate that exposure to input after production gave learners the opportunity to pay closer attention to formal aspects, that is, the English simple present tense. In other words, pushed output can induce the learners to process input effectively. Thus output served as an attention-focusing device of relevant elements of the input (Leeser, 2008).

The findings in this study also support the effectiveness of dictogloss tasks in drawing attention to language form, as well as prompting learners to reflect on their own output. As Swain (1995) suggested, tasks which encourage reflection on language and are oriented to getting meaning across can help us to investigate how learners' explicit hypothesizing contributes to language development. However, collaborative interaction had no effect in the production of any of the target forms. Finally, retrospective comments after the text reconstruction task in the present study showed that learners primarily focused on content.

As mentioned above, this is an exploratory study that has investigated the implementation of a dictogloss task in a CLIL classroom and it can be considered as a first step in examining whether and how an output-input cycle in a dictogloss task can be beneficial in this context. More specifically, we have analyzed these learners' noticing of English verb tenses embedded in a dictogloss task and how the learners' production is affected by subsequent input. But there are clearly limitations in the study. Firstly, a larger number of participants would have been necessary to provide more robust results and a delayed posttest could have been used in order to determine the extent to which the results reported here would be maintained.

The present study, however, suggests further lines of research that could be tackled in future work. For example, further research should be done on how CLIL learners interact in subject-specific tasks and whether or not explicit reflection on language in collaborative work occurs. In this vein, some voices are already pointing at the need to employ formfocused tasks in CLIL (Dalton-Puffer, 2011). Further research should also focus on how the purported dual focus on form and content is established in the CLIL classroom. Finally, the relative effectiveness of different output tasks should be empirically tested with regards to the noticing function of output in further investigation.

\section{REFERENCES}

Alegría de la Colina, A. and García Mayo, M.P. (2007). "Attention to form across collaborative tasks by low-proficiency learners in an EFL setting”, in M. P. García Mayo (ed.), Investigating Tasks in Formal Language Settings. Clevedon: Multilingual Matters, 91-116.

Ball, P., Beobide, H. y Muñoa, I. (2004). Cómo enseñar ciencias sociales en inglés. [How to teach Social Sciences in English] In Cap al Plurilingüisme des del'Ensenyament-Aprenentatge de la Segona Llengua - III Jornades Institut Europeu de Programes d'Inmersió. [Towards Multilingualism from Second Language Teaching/Learning - 3rd Symposium of the European Institute of Immersion Programs] Barcelona: IEPI.

Bardovi-Harlig, K. (2000). Tense and aspect in second language acquisition: Form, meaning, and use. Malden, MA: Blackwell Publishers. 
Basterrechea, M. and García Mayo, M. P. (2013). "Language-related episodes during collaborative tasks: A comparison of CLIL and EFL learners", in K. McDonough \& A. Mackey (eds.), Interaction in Diverse Educational Settings. Amsterdam: John Benjamins, 25-43.

Beobide, H. and Ball, P. (2008). Social Sciences. Compulsory Secondary Education. Second cycle. Vol 3: The story goes on ... Donostia-San Sebastián: Ostadar.

Council of Europe. (2001). Common European Framework of Reference for Languages: Learning, Teaching, Assessment. Cambridge: Cambridge University Press.

Coyle, D. (2007). "Content and language integrated learning: Toward a connected research agenda for CLIL pedagogies", in The International Journal of Bilingual Education and Bilingualism, 10: 543-62.

Dalton-Puffer, C. (2011). "Content-and-language integrated learning: From practice to principles?", in Annual Review of Applied Linguistics 31: 182-204.

Fernández Dobao, A. (2012). "Collaborative writing tasks in the L2 classroom: Comparing group, pair and individual work", in Journal of Second Language Writing, 21, 1: 40-58.

García Mayo, M.P. (2002). "Interaction in advanced EFL pedagogy: A comparison of form-focused activities", in International Journal of Educational Research 37, 3-4: 323-41. Special issue on "The role of interaction in instructed language learning". Guest Editors: M.P. García Mayo and E. Alcón Soler.

Gass, S. (2003). "Input and interaction", in C. Doughty \& M. Long (eds.), The Handbook of Second Language Acquisition. Oxford: Blackwell, 224-55.

Gass, S. and Mackey, A. (2000). Stimulated Recall Methodology in Second Language Research. Mahwah, NJ: Lawrence Erlbaum Associates.

Izumi, S. (2002). "Output, input enhancement, and the noticing hypothesis: An experimental study on ESL relativization", in Studies in Second Language Acquisition, 24: 541-77.

Izumi, S. and Bigelow, M. (2000). "Does output promote noticing and second language acquisition?", in TESOL Quarterly, 34: 239-78.

Izumi, S., Bigelow, M., Fujiwara, M. and Fearnow, S. (1999). "Testing the output hypothesis: Effects of output on noticing and second language acquisition", in Studies in Second Language Acquisition, 21: 421-52.

Kuiken, F. and Vedder, I. (2005). "Noticing and the role of interaction in promoting language learning ", in A. Housen \& M. Pierrard (eds.), Investigations in Instructed Second Language Learning. Berlin: Mouton de Gruyter, 353-82.

Leeser, M. J. (2008). "Pushed output, noticing, and development of past tense morphology in content-based instruction", in Canadian Modern Language Review, 65, 2: 195-220.

Lorenzo, F., Casal, S. and Moore, P. (2009). "The effects of Content and Language Integrated Learning in European Education: Key findings from the Andalusian bilingual sections evaluation project", in Applied Linguistics, 31, 3: 418-42.

Mackey, A., Gass, S. and McDonough, K. (2000). "How do learners perceive interactional feedback?", in Studies in Second Language Acquisition, 22: 471-97.

Montrul, S. (2005). The Acquisition of Spanish. Amsterdam: John Benjamins.

Nassaji, H. and Tian, J. (2010). "Collaborative and individual output tasks and their effects on learning English phrasal verbs", in Language Teaching Research, 14, 4: 397-419.

Nikula, T. (2012). "On the role of peer discussions in the learning of subject-specific language use in CLIL", in E. Alcón Soler \& M.P. Safont-Jordà (eds.), Discourse and Language Learning across L2 Instructional Settings. Amsterdam: Rodopi, 133-154.

Schmidt, R. (1990). "The role of consciousness in L2 learning", in Applied Linguistics, 11: $129-58$. 
Schmidt, R. (1995). "Consciousness and foreign language learning: A tutorial on the role of attention and awareness in learning ", in R. Schmidt (ed.), Attention and Awareness in Foreign Language Learning. Honolulu: University of Hawai'i Press, 1-63.

Selinker, L. (1972). "Interlanguage", in International Review of Applied Linguistics, 10: 20931.

Sharwood Smith, M. (1993). "Input enhancement in instructed SLA", in Studies in Second Language Acquisition, 15: 165-79.

Song, M.-J. and Suh, B.-R. (2008). "The effects of output task types on noticing and learning of the English past counterfactual conditional", in System, 36: 295-312.

Storch, N. (1999). "Are two heads better than one? Pair work and grammatical accuracy", in System, 27: 363-74.

Storch, N. (2005). "Collaborative writing: Product, process and students' reflections", in Journal of Second Language Writing, 14: 153-73.

Storch, N. (2007). "Investigating the merits of pair work on a text editing task in ESL classes", in Language Teaching Research, 1, 2: 143-59.

Suzuki, W. and Itagaki, N. (2007). "Learner metalinguistic reflections following output-oriented and reflective activities", in Language Awareness, 16, 2: 131-46.

Swain, M. (1985). "Communicative Competence: Some roles of comprehensible input and comprehensive output in its development ", in S. Gass \& C. Madden (eds.), Input in Second Language Acquisition. Rowley, MA: Newbury House, 235-53.

Swain, M. (1995). "Three functions of output in second language learning", in G. Gook \& B. Seidlhofer (eds.), Principle and Practice in Applied Linguistics. Oxford: Oxford University Press, 125-44.

Swain, M. (1998). "Focus on form through conscious reflection", in C. Doughty \& J. Williams (eds.), Focus on Form in Classroom Second Language Acquisition. Cambridge: Cambridge University Press, 64-81.

Swain, M. (2005). "The output hypothesis: Theory and research", in E. Hinkel (ed.), Handbook of Research in Second Language Teaching and Learning. Mahwah, NJ: Lawrence Erlbaum, 471-83.

Swain, M. and Lapkin, S. (2001). "Focus on form through collaborative dialogue: Exploring task effects", in M. Bygate, P. Skehan, \& M. Swain (eds.), Researching Pedagogic Tasks: Second Language Learning, Teaching, and Testing. New York: Longman, 99-118.

Thornbury, S. (1997). "Reformulation and reconstruction: Tasks that promote "noticing"", in ELT Journal, 51: 326-35.

Uggen, M.S. (2012). "Reinvestigating the noticing function of output", in Language Learning, 62, 2: $505-40$.

VanPatten, B. (1996). Input Processing and Grammar Instruction. New York: Ablex.

VanPatten, B. (2000). "Thirty years of input (or intake, the neglected sibling)", in M. Anderson, C. Klee, F. Morris, E. Tarone \& B. Swierzbin (eds.), Social and Cognitive Factors in Second Language Acquisition. Selected Proceedings of the 1999 Second Language Research Forum. Somerville: Cascadilla Press, 287-311.

VanPatten, B. and Cadierno, T. (1993). "Explicit instruction and input processing", in Studies in Second Language Acquisition, 15, 2: 225-43.

Wajnryb, R. (1990). Grammar Dictation. Oxford: Oxford University Press. 


\section{Appendix}

East Berlin, 1961

People living in the East can no longer go to West Berlin under any circumstances. In other words, a young man who lives in West Berlin but works in the East automatically loses his job; families are separated; students can't go to university.

Before the wall was built, millions of people escaped to the West for private, political or economic reasons. But now only by building the wall the communist East German regime stops the exodus.

President Khrushev says that the wall protects the East Germans from the American spies. In fact, the wall is so high that if somebody wants to climb it, he might get injured, or even killed by East German soldiers.

\section{ACKNOWLEDGements}

The research was supported by the following research grants: UFI11/06 from the University of the Basque Country (UPV/EHU), and IT-311-10 from the Basque Government. 